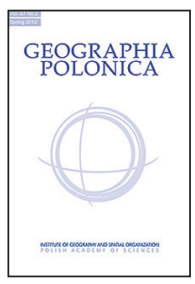

\title{
POLISH ECONOMIC MIGRANTS IN IRELAND, 2004-2007
}

\author{
Roman Matykowski • Alicja Andrzejewska \\ Adam Mickiewicz University \\ Institute of Socio-Economic Geography and Spatial Management \\ Dzięgielowa 27, 61-680 Poznań: Poland \\ e-mail addresses: mat@amu.edu.pl • alicja.andrzejewska@onet.pl
}

\begin{abstract}
On the accession of Poland (and nine other states) to the European Union on 1 May 2004, three countries decided to open fully their labour markets to Poles (United Kingdom, Ireland, Sweden). Even before that date, Poles emigrated to various European countries in search of seasonal work, especially in agriculture (e.g. collecting fruits and vegetables), either relying on their German passports (e.g. residents of Silesia) or working illegally. There were several factors that made the labour market of the British Isles particularly popular with Poles, including their knowledge (even if, for some, it was relatively poor) of English, especially among the young (in the 1990s it became the basic and dominant foreign language taught at Polish schools), and the relatively high earnings. This is why research was conducted on Polish economic migration to the Republic of Ireland in the initial stage of the opening of its labour market, i.e. in the years $2004-2007$. The potential difference model was employed to delimit the leading areas attracting Polish migrants to Ireland. The Polish migrant is characterised on the basis of the survey research that has been conducted, and the various manifestations of the socio-cultural life of Poles in Ireland are identified. An analysis is also made of the facilities catering to Polish migrants in the urban space of Cork, one of the major clusters of Poles outside the Irish capital.
\end{abstract}

\section{Key words}

economic emigration - potential difference model - Ireland - Little Poland

\section{Introduction}

The mobility of people at the world scale is, in the opinion of 'globalists', an inalienable characteristic of globalisation that is closely connected with other aspects of this process, like the globalisation of transport, information, and financial markets (Dutkowski 2008). Migrants increasingly tend to be more enterprising than native members of a given local community or participants of a regional labour market (Koser 2007). There has also appeared a new category of migrants - 'postmodern nomads' - who are an element of a deterritorialised society and to whom the place of work is not important, when compared to the benefits that flow from the attainment of a strong desire for selfactualisation Bauman 1996). Economic migration is often understood as "spatial shifts of the economically active population intended to improve one's own situation in life and that of one's family members" (Nakonieczna 2007: 12), or "forms of mobility that involve undertaking paid work or other activities intended to bring profit" (Kaczmarczyk 2005: 21). The latter author defines international migrations as any type of mobility involving "the crossing of a state border, irrespective of the duration of the movement" (Kaczmarczyk 2005: 21). Sometimes, however, a minimum duration of such migrations is postulated, from 2 months (seasonal) to 12 months (Więckowski 2008), in order to differentiate them from tourist visits abroad (Romaniszyn 2003; Koser 2007). Jaźwińska (2001) emphasises the variety of modern forms of international migration involving such aspects as the type of economic activity during migration (work or another occupation), its duration, the migrant's links with his household, and the legality of his stay abroad. On the basis of these criteria, four types of migrant have been distinguished: (1) commercial (making short trips with the basic aim of buying or selling commodities), (2) settlers (or those planning to settle in another country); (3) contract workers (temporal, working legally abroad) 
and persons studying or staying on a scholarship, as well as their families, not working but accompanying those who are legally employed; and (4) those who go abroad for a limited time to perform work arranged earlier by friends, family members, etc.

The aim of the present study is to characterise the most salient aspects of the economic migrations of Poles to Ireland in the years 2004-2007. Three issues are addressed in detail: (1) areas with an excess/deficit of accessibility as poles of attraction/repulsion for Polish migrants; (2) the Polish migrant in the light of survey research; and (3) the socio-cultural life of Poles in Ireland and the facilities catering to Polish migrants, mainly in the urban space of Cork.

Use was made of primary and secondary sources of information. The primary material included data collected in survey research (carried out in 2007 with the help of Polish Catholic chaplains working in Ireland), interviews, participatory observation, and a field survey, especially in Cork city. The secondary material was largely statistical data presented in the publications of the Irish Central Statistics Office and the Polish Central Statistical Office (GUS). Another source was the press (including websites) devoted to migration issues, published in both Poland and in Ireland.

\section{Migrations abroad of Poles today} "Migration means life and progress;
a sedentary population, stagnation"
Ravenstein 1885

In the 1990s, some 220,000 Poles left the country for good, mostly as a result of the opening of international frontiers, a gradual elimination of passport barriers, and a change in the migration policies of the destination states (Długosz 2007; Grabowska-Lusińska 2008). The possibility for citizens of Poland to go freely abroad in search of work appeared on 1 May 2004 when the country joined the European Union. At that time only three members of the 'Old Fifteen' - Ireland, Sweden and Great Britain - decided to liberalise fully access to their labour markets for citizens of the newly admitted states. The rest of the EU-15 feared that the inflow of Polish emigrants would destabilise their domestic labour markets, and that some of those migrants would also come in search of better unemployment benefits. Since these fears turned out to be greatly exaggerated, in May 2006 Polish citizens gained access to the labour markets of the southern European countries: Spain, Portugal, Greece and Italy (since July), as well as the Scandinavian states: Finland and Iceland (an EFTA member). In the next year, 2007, France and Luxembourg opened their labour markets to Poles. It should be mentioned that Polish citizens could also take up legal work in the countries that joined the European Union together with Poland (only Malta required additional permits).

According to the National Census of the Population and Housing taken in May 2002, there were 786,000 Poles then living abroad, largely in Germany $(294,000)$ and the United States of America $(158,000)$. Great
Britain and Italy accounted for a marginal proportion, and Ireland did not appear in the ranking at all. This changed with Poland's accession to the European Union. The distribution of Polish economic migrants in the world (because, according to the GUS data, $80-90 \%$ of Poles who left in the period 2004-2007 were economic emigrants) depended primarily on the accessibility of labour markets in the individual countries (GUS 2007). At the close of 2006, there were about $1,950,000$ Poles staying outside the country's borders (which means that the number of migrants grew 2.5 times in comparison with the 2002 figure). A decided majority of them (as many as 1,550,000 in 2006 and $1,860,000$ in 2007), selected a state belonging to the European Union as their destination. In the period 2004-2007 the number of Polish migrants to the EU countries also grew 2.5 times (GUS 2008). In 2007, the greatest proportion of temporary emigrants from Poland (staying abroad for at least two months) lived in Great Britain (35.8\% of all Polish emigrants to European countries), followed by Germany (25.5\%), Ireland (10.4\%), The Netherlands (5.1\%), and Italy (4.5\%).

\section{Ireland's attraction}

\begin{abstract}
"Let Poles come here in the greatest numbers!" President Mary McAleese, after the Rzeczpospolita daily,
\end{abstract}

4 April 2006

In 2007 Ireland had 4.3 million residents, and its population density was 61 persons $/ \mathrm{km}^{2}$, double the figure of Poland (122 persons $/ \mathrm{km}^{2}$ ). The demographic situation of Ireland has changed significantly over the last two centuries. In 1841 it had a population of 6.5 million (CSO 2004, NCG 2010). The potato plague from America that hit the island in the years 1846-1848 via continental Europe completely destroyed its potato crops - the staple food of the Irish in that period. Since the mid-19th century there was a steady decline in the population number owing to massive emigration (mostly to the USA, Canada, Australia and Great Britain - approximately 2 million people) and deaths from famine (approximately 1 million). The country started to register a slow increase in the population number only since the 1960s. In 2007 emigrants from Poland accounted for about $4.6 \%$ of the Republic's inhabitants.

On 1 January 1973 Ireland joined the European Economic Community (EEC), and while this step in itself did not bring major benefits immediately, it meant that it was necessary to implement beneficial reforms. During the first years of membership, one of the chief advantages for the Irish economy was Ireland's participation in the Common Agricultural Policy (Grabowska \& Lusiński 2005). However, the 1970s were a period of very high inflation, which continued to hamper economic growth. It was only in the 1990s that significant reforms were introduced, bringing about an increase in the efficiency and productivity of the economy, thus also improving the situation of the labour market. Earlier, in the 1980s, Ireland had the greatest structural labour problems of all the European states: in the 
years 1986-1987 its unemployment rate amounted to about 17\% (Grabowska \& Lusiński 2005). In the later 1990s, this figure started to decline steadily, to reach $5.7 \%$ in 1999 and to stabilise since 2000 at about $4.3 \%$ (4.7\% in 2007). The Irish labour market has been transformed in a surprisingly short period of time from one with labour surpluses into one that required an inflow of labour from without. By comparison, in Poland the unemployment rate exceeded $15 \%$ in 2000 , soaring to $19.1 \%$ in 2004 and falling again in 2006 to slightly under $15 \%$.

At this point it is worth noting the fact that, when entering the EEC, Ireland had kept its corporate tax at $10 \%$. Investors, mostly American, decided to trust in the country's success and put their money in sectors requiring the use of high technology, thus creating new jobs. The resources from European funds were also skilfully employed in that period to carry out the necessary reforms of the education system, which were intended to help retrain workers in the unprofitable sectors of the economy, or to activate women. In the late 1980s and early 1990s, the supreme goal of the authorities was to reduce the budget deficit. The measures taken in this field ultimately allowed workers to enjoy stable higher wages, ensured employers a more rapid increase in the income of their firms without having to worry about the previously frequent strikes, and brought the government, among other things, a reduction in the number of the unemployed. This was the next stage in the development of Ireland whose special feature was an absolute and a relative increase (with reference to the EU mean) in the country's per capita GDP (Grabowska \& Lusiński 2005). While in 1972 this index in Ireland was a mere $62 \%$ of the EU mean, in 2002 it exceeded the average by $20 \%$. The biggest jump in the GDP figure took place over the last ten years - about 42\% (IDA Ireland 2007).

One notable characteristic of this period was Ireland's expansion into the markets of the high-technology products mentioned above, i.e. high-value goods. This was certainly an effect of foreign direct investment, which was especially visible in the information and electronic industries, which allowed Ireland to come first (before the USA) among software exporters in 2000. This is what caused one-third of American investment in this field in the European market to be located in Ireland, which also ensured the development of Irish firms specialising in profitable services and software. Dynamic growth was also recorded by the pharmaceutical industry, which gradually moved to the position of a leader and became an 'engine' for the entire economy (Grabowska \& Lusiński 2005).

When analysing the network of transport links between Poland and Ireland, one can note at least five possibilities of travel. On 26 May 2004 the first direct air routes were opened, served by PLL LOT and Aer Lingus. In 2007 Warsaw was connected with the Irish capital by 20 flights a week, while Cracow had 12 flights, Wrocław had 11, Gdańsk had 10, Katowice had 8, Szczecin had 6, Poznań had 5, Łódź had 3, and Bydgoszcz and Rzeszów had 2 each. Warsaw, Cracow, Gdańsk and Katowice also had air connections with Cork (3-4 a week), and Cracow and Wrocław had connections with Shannon. In that year there were four principal operators serving the Poland-Ireland route: Irish Ryanair and Aer Lingus, Hungarian Wizzair, and Polish Centralwings, but for a variety of reasons the number of links often changed, and is still changing today.

In 2007 there were two coach lines offering regular journeys between Poland and Ireland: Eurolines Poland and Polonia Transport. The journey by coach led via Great Britain and lasted just over two days, but was relatively cheap. It cost about 500 zlotys one way (though the price could vary - for example, with the season), which amounted to $70 \%$ of the price of a regular return ticket. The buses ran primarily to major Irish cities, like Dublin or Cork. In sum, it was possible to get there from at least 74 towns in Poland, mostly former voivodeship cities, but also today's major poviat capitals.

Other modes of travelling to Ireland are by car (more than 2,000 km), which involves one or two ferry passages (e.g. from Holyhead to Dublin Port or Dún Laoghaire, and from Fishguard to Rosslare), as well as by train (via Berlin, Brussels and London).

\section{The potential as a measure of the spatial accessibility of an area from the point of view of the distribution of Polish-born residents in Ireland}

\author{
"Ireland, Dublin give me tremendous drive. \\ Here dreams come true" \\ Patrycja Grzybek-Jasińska, after the Polityka weekly,
} 17 March 2007

The accessibility of places (towns) and areas (regions) is a property that proves them to be useful to people who want and are able to reach them. To measure the accessibility of a system of territorial objects, use can be made, for example, of the potential model and potential-based indices Chojnicki 1966). In the case of Ireland, the territorial reference system employed was its division into 26 counties. The potential was calculated according to the following potential model (Czyż 1996: 49):

$$
V_{i}=\sum_{j=1}^{n} \frac{M_{j}}{d_{i j}}+\frac{M_{i}}{d_{i i}}
$$
assuming that $k=1$ and $j \neq i$,
where:
$V_{i}$ - the potential of unit $i$;
$M$ - the mass of unit $j$;
$M_{i}$ - the mass of unit $i$;
$d_{i j}$ - the distance between $i$ and $j$;
$d_{i j}^{i j}$ - the distance of point $i$ to itself (internal distance).

The distances between county capitals were measured in a straight line (in $\mathrm{km}$ ), and the internal distances of counties were determined from the formula (Matykowski 1990: 87): 


$$
d_{i i}=0,282 \sqrt{A}
$$

where: $A_{i}$ - the area of a county (in $\mathrm{km}^{2}$ ).

Having determined the potential of the counties in terms of the distribution of the Irish population and the distribution of officially registered Polish residents in 2006, the conception of potential difference was employed to delineate areas of a potential surplus and a potential deficit. In order to bring those two distributions to a common reference level, it was assumed that the sum of the values of each of the potentials for the entire spatial system of county capitals under analysis was equal to 100\% (Matykowski 1990: 97):

$$
\sum_{j=1}^{26}=100 \%
$$

Next percentages were calculated at individual points of the system, i.e. county seats (Matykowski 1990: 97):

$$
V_{i}(\%)=\frac{V_{i}}{\sum_{j=1}^{26} V_{i}} * 100
$$

Before turning to the effects of attraction of Polish migrants on the basis of an analysis of potential differences, the distribution of Poles in Ireland should be examined. In 2006 nearly one-third of them (31.2\%) lived in County Dublin. More than 30\% of Polish migrants - according to Irish data - were concentrated in four counties: Cork (13.4\%) and Limerick (5.3\%) in the south of the island; Galway (6.6\%) on its western margins, and Kildare (6.4\%) in the county adjacent to the Irish capital. At this point it is worth examining the Irish data on Polish emigrants. These sources establish the number of Poles on the basis of Personal Public Service (PPS) numbers issued to them; in 2006 they estimated their number in the country at 60,000 (CSO 2007), while Polish migration reports spoke of 200,000 (unpublished approximate estimation of the Polish Embassy in Dublin, 2007). The PPS number - the Irish equivalent of the Polish NIP number - is issued once (after which some of their bearers could return to Poland).

A comparison of the distribution of the analysed potentials determined for Irish residents of Polish origin and indigenous ones shows there to be two regions where one potential predominates over the other, or two areas with a strong pull effect (Fig. 1): (1) in the east of the country, with County Dublin as the centre $\left(\Delta V_{i}=+1.40\right)$, and (2) in the southern and south-western parts of the island, with the centre in County Cork $\left(\Delta V_{i}=+0.22\right)$. In turn, the entire northern part of the country displays a marked deficit of accessibility in terms of the phenomenon under study. A deep depression can be observed in the zone bor- dering on the United Kingdom (Northern Ireland). The lowest figure $\left(\Delta V_{i}=-0.69\right)$ is registered in County Louth (with its capital Dundalk) and County Donegal $\left(\Delta V_{i}=-0.43\right)$. It is worth noting that those are areas that had the highest unemployment rate in Ireland in the years 2005-2007.

\section{Economic migrations of Poles to Ireland in the light of the survey research}

\author{
"There is an opinion in Ireland that all emigration \\ communities are similar, but this is an altogether \\ mistaken way of thinking"
}

Gavan Titley, after the Polski Herald weekly, 12 January 2007

The research was conducted in February and then between June and December 2007. Questionnaires were filled by Poles working in Ireland at that time, mostly in County Cork (53.0\% of the respondents) and Dublin $(39.7 \%)$; there were much fewer in six other counties (8.3\%). There were 300 questionnaires which the respondents received either directly or via electronic mail. Males predominated among the respondents (57\%), and this sex structure corroborates the observation that migratory territorial mobility is a domain of men rather than women (Mioduszewska 2008). The largest group among those polled was that aged 21-30 (71\%). Most respondents had secondary and higher education (75\%), which corroborates the findings by, for example, the ARC Rynek i Opinia Research Institute among Polish emigrants in the British Isles. They showed that there were decidedly more Poles with higher education living abroad than in the population residing in Poland (CPWM 2007). The majority of respondents gave a town as their place of origin and only 12 gave the countryside. However, this information cannot be treated as fully reliable because migrants tend to indicate as their place of origin the nearest medium-sized town or the seat of a poviat. The greatest number of respondents came from the voivodeships: Śląskie (54 persons) as well as Wielkopolskie and Mazowieckie (34 persons from each). However, on relativising the data to the population number of a voivodeship, Opolskie and Lubuskie come first and second, and Ślaskie only third. In relative terms, the fewest respondents came to Ireland from the Łódzkie and Świętokrzyskie voivodeships.

An analysis of the years of arrival in Ireland shows that the largest proportion of people (75\%) decided to emigrate in the years 2006 and 2007. These data coincide with the highest number of PPS numbers issued to Poles in these years. One can observe a cyclicity of departures from Poland to Ireland within the year. Most people arrived in the Emerald Isle in the spring and summer months, especially May (12\%) and June (13\%). Equally frequent were flights in September, while the least 'popular' were departures in the winter months (December, January) as well as in April and August (Fig. 2).

Among factors that influenced their decision to come to Ireland rather than anywhere else, the respondents first listed friends that had arrived there earlier (52\%) and 'prepared the way for them', in 


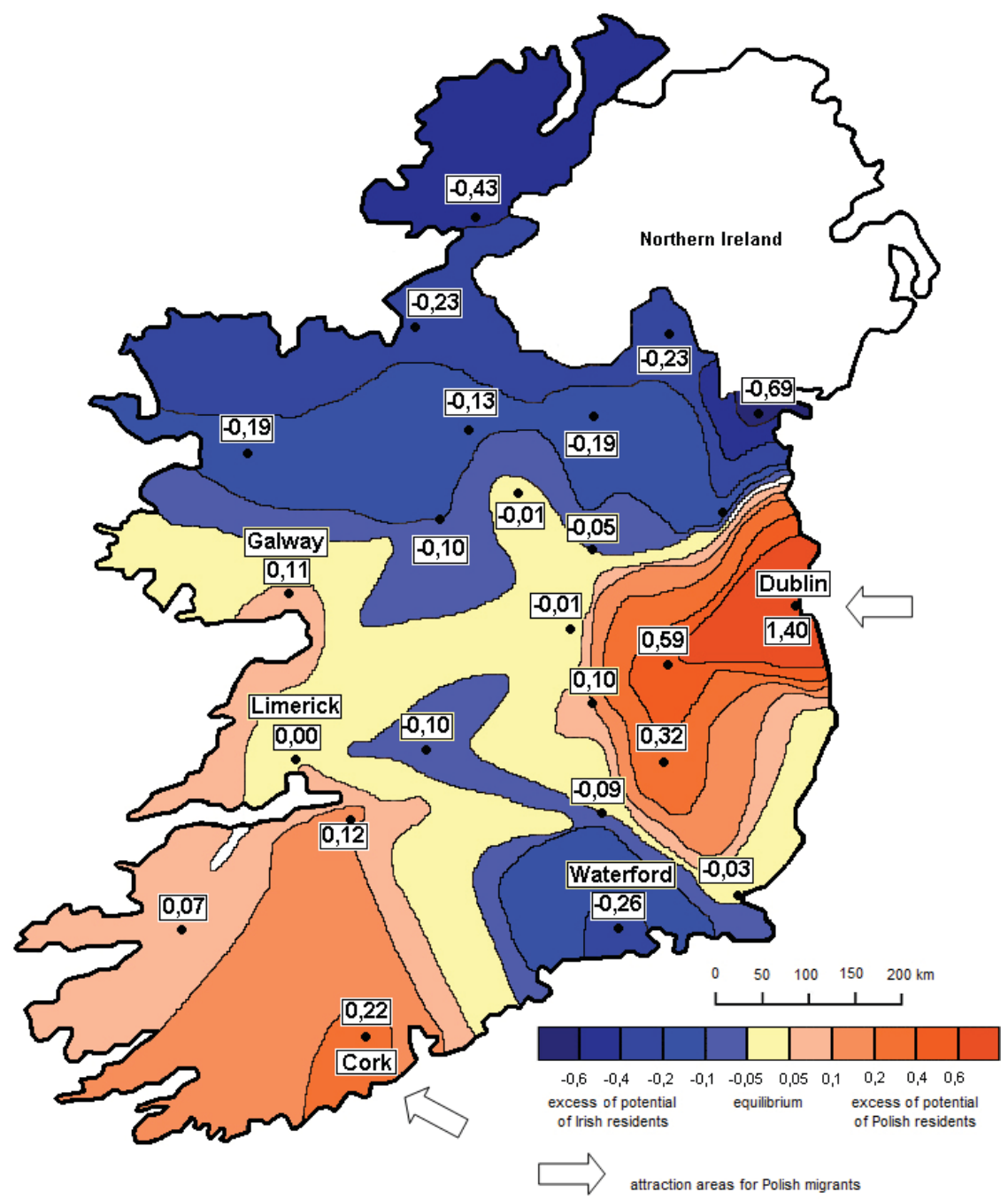

Figure 1. Comparison of the potential of Polish and Irish residents in Ireland in 2006.

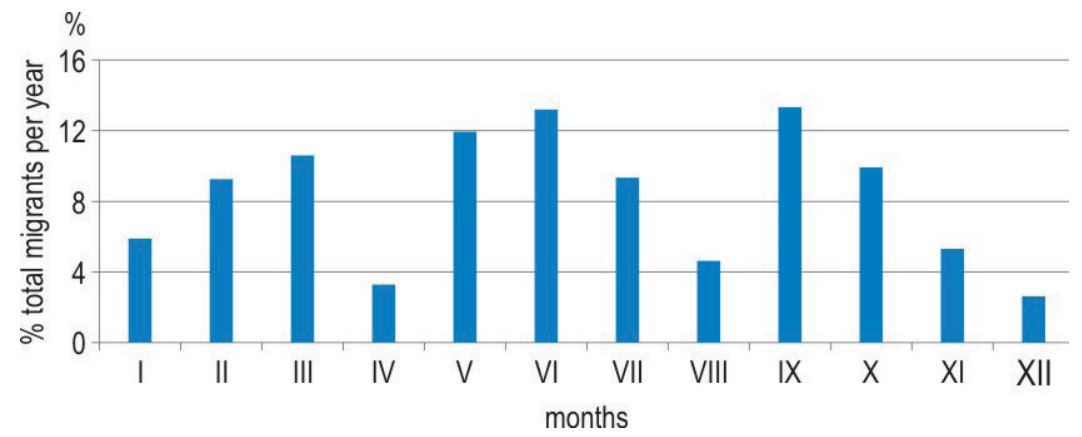

Figure 2. Arrivals in Ireland in the period 2003-2007 by month. 
a manner of speaking. For nearly one-fifth (18\%) this was a matter of chance, and an even lower percentage ascribed a significant role to the mass media, like the Internet $(8 \%)$ or the press (5\%).

A significant majority of respondents highly appreciated the friendly attitude of both the Irish (81\%) and Poles (51\%). However, there were also complaints about discrimination in the workplace by the citizens of the host country (7\%).

What proved interesting was the structure of employment of the respondents in the various sections of the Irish economy. The largest group included those working in hotels and restaurants (22\%) as well as in transport, storage and communication (19\%). The next sectors where the respondents found employment were trade (14\%) and domestic personnel (12\%), this role mostly being performed by Polish women working as cleaners or au pairs. Construction, accounting for the largest proportion of foreign labour in recent years, provided jobs for $12 \%$ of the respondents. It might be added by way of comparison that of the County Dublin residents polled, the largest proportion worked in transport and storage (42\%), while a substantial segment had jobs in construction (21\%) and as a domestic help (15\%). One should also note that more than half of the respondents currently working in Ireland did not have a formally legalised job. responses were also given by people aged 26-30: as many as $52 \%$ of them had no problem finding a job.

Only a low percentage of the respondents admitted to a very good knowledge of English (8\%). Predominant among them were persons with a higher education and those aged 21-30. No knowledge at all was declared by $14 \%$ of those polled, nearly half of whom (48\%) had a vocational education. A substantial percentage of people with secondary (48\%) and higher (25\%) education described their language skills as poor.

When analysing the significance of the knowledge of the language when seeking employment, a mere $6 \%$ of the respondents decided that in their case it was of no importance. By age group, those in their 30 s were the most successful, irrespective of their knowledge of English. In the opinion of 50\% of people with vocational education, knowledge of English was of marginal significance in their search for work. All the respondents aged $15-20$ and $56 \%$ of those aged $26-30$, as well as a substantial percentage (58\%) of those with higher education, assessed knowledge of the language as being important or very important.

One of the major aspects of migration is the issue of a return to the home country. A question on this subject proved difficult for many respondents; as

Table 1. Respondents by level of education and wages.

\begin{tabular}{|l|c|c|c|c|c|c|c|c|c|c|}
\hline \multirow{2}{*}{$\begin{array}{l}\text { Wage } \\
\text { per hour }\end{array}$} & \multicolumn{2}{|c|}{ Primary } & \multicolumn{2}{c|}{ Basic vocational } & \multicolumn{2}{c|}{$\begin{array}{c}\text { Technical } \\
\text { vocational }\end{array}$} & \multicolumn{2}{c|}{ Secondary } & \multicolumn{2}{c|}{ Higher } \\
\cline { 2 - 12 } & females & males & females & males & females & males & females & males & females & males \\
\hline Under $€ 8$ & & & & & & & 4 & 8 & 2 & 16 \\
$€ 8-10$ & & & 8 & 10 & 6 & 6 & 40 & 26 & 36 & 10 \\
$€ 10-12$ & 2 & 2 & 2 & 12 & 2 & 10 & 6 & 36 & 8 & 22 \\
Over $€ 12$ & & & & 4 & & 4 & 2 & 10 & 10 & 12 \\
\hline
\end{tabular}

There were some differences among the respondents in hourly wages between men and women. As many as $70 \%$ of women received the lowest pay $(€ 8.65$ in 2007), while men were usually offered the rate of $€ 10-12$. A factor substantially affecting the respondents' earnings was their education (Tab. 1): the lowest hourly rate was reported by those with secondary education. This is also the group where the differences in wages were the widest. The highest earnings (in excess of $€ 12 / h$ ) were mostly reported by people with higher education.

The respondents also expressed their opinions about finding employment in Ireland. For 51\% of them this was "rather easy" or "easy", and 19\% had found a job without any difficulty. Predominant among those for whom this was a more problematic issue were people with a secondary education and those belonging to the youngest $(<20)$ and the oldest age groups. There were no complaints in this respect on the part of respondents with a higher education and, interestingly enough, those with primary education. Optimistic many as $17 \%$ of them were unable to provide a definite answer, giving as their reason the uncertainty of desirable changes in the situation, mostly economic and political, in Poland. As many as 36\% declared a wish to return to the homeland, while $26 \%$ considered this response, but harboured doubts. In turn, interviews in Cork showed that graduates of schools and universities, and those who had been long unemployed in Poland were less motivated to return to the country. One should also note that of the respondents with a higher education, $40 \%$ were determined to return to Poland. Similar results were obtained in research undertaken in September 2006 by SMG/KRC Poland, among people who were only planning to emigrate from the country. Even though $55 \%$ of them declared a wish to return, here, too, as many as $24 \%$ were unable to give a decisive answer to this question (Ciacek 2007).

Ewelina Jurczak undertook similar survey research in 2007 among 80 young Poles (aged 19-33) living in Dublin with the help of two pollsters (Jurczak 2009). They found that nearly $44 \%$ of young Polish emigrants 
went to Ireland sight unseen, while $37 \%$ had first received assistance and information from friends or relatives living on the island. Most respondents also indicated several factors that had influenced their decision to embark upon economic migration, the most important being: (a) a wish to earn some money on the side (49\%), (b) a wish to achieve some stability in future life due to the economic success in Ireland (47\%), and (c) a wish to see a country other than the home country (47\%) and higher earnings (39\%), the latter put succinctly as: "In Poland you worked for pennies, and in Ireland you can make good money".

\section{Polish socio-cultural initiatives in Ireland}

"When I open our newspapers, I can see articles in Polish. When I turn on the radio, I can hear Polish commercials. When I walk in Dublin, I can see Polish shops; all this has become part of Irish everyday life. And has greatly enriched us" President Mary McAleese, after Rzeczpospolita daily, 4 April 2006

Each migrant brings with him the culture of his earlier place of residence and often it is then confronted with a mixture of other cultures, and the migrant has to work out his attitude towards the destination place (Łuczak 2007). The stronger the group of representatives of a given culture or from a given country, the more frequent and sharper this situation. It leads to, among other things, the building of social capital consisting in the formation of support groups and information exchanges in the foreign country (Łuczak 2007).

One of the manifestations of the activity of Polish residents in Ireland in the political sphere was the Polish parliamentary election of 21 October 2007. There were 21,300 Polish citizens registered as eligible voters, of whom 14,000 actually went to the polls in four constituencies: in Dublin (two), Limerick and Cork, giving a voter turnout of $65.7 \%$. Some voters might have given up because of very long queues to the polling stations, and in the rain, too. This election in Ireland was won by Civic Platform (77.2\% of valid votes), while Law and Justice captured $10.5 \%$, and the parties supported by the rural and small-town electorate in Poland (i.e. the Polish Peasant Party and Self-Defence) commanded a mere 1.1\%. It is worth emphasising that two years earlier, in 2005, in both the parliamentary and presidential elections there was only a single district election commission in Ireland (in Dublin). Then, a mere 1,200 Polish citizens registered for the parliamentary election, of whom 71.9\% actually turned up at the polls. Civic Platform captured the majority of valid votes in this election as well (64.0\%). In the 2005 presidential election, there were 2,300 eligible Polish citizens, and the voter turnout was $70.3 \%$ (in the 1 st round of voting; the 2 nd round is not held abroad). Unlike in Poland, the winner was the Civic Platform candidate, Donald Tusk (74.4\% of valid votes), while the Law and Justice candidate, Lech Kaczyński, came a distant second (14.5\%). One can say, therefore, that in 2007, for the first time, "our new emigration" became a bargaining chip of most electoral committees (Nasz Głos 2007).
There is a plethora of social activities launched among Polish emigrants. In 2007, one of them was the grand finale of the Great Orchestra of Christmas Charity, organised in Ireland for the second time. Its committees were set up, with a flourish, in three cities (Dublin, Cork and Galway) and the events included concerts, fund-raising and firework displays, as in Poland.

It is worth noting, among the other ventures in this sphere, the fact that in December 2007 the Barka foundation started operating in Dublin (in cooperation with other NGOs and public institutions) under the project "Network of Economic Migrants Integration Centres". Its aim is to provide support in such fields as information, employment consultancy, and helping people who have failed to find a job and "their place abroad" to return to Poland (Sadowska 2008).

Large-scale Polish cultural events are also organised in Ireland, like the exhibition of Polish painting masterpieces that took place in the National Gallery between 16 October 2007 and 27 January 2008 in Dublin. Its theme was "Paintings from Poland. Symbolism to Modern Art (1880-1939)", and the 74 pictures on show had been borrowed from the Polish museums in Warsaw, Cracow and Zakopane, and from private collections (information after MyCork Polish Association, www.mycork.org, 2007 and 2009). On 17 October 2007 an exposition was organised in Dublin entitled "Ireland in the eyes of children", presenting works by the youngest compatriots currently living with their parents in Ireland. The patrons of this venture were representatives of the authorities dealing with the integration of the two countries.

When analysing the Polish press in Ireland, one should note the variety of its forms and content. The titles usually mentioned by the respondents were Polski Express, Gazeta Polska, Szpila and Polski Herald (Tab. 2). However, new titles keep appearing all the time, e.g. Irlandzki niezbędnik - twoje imigracyjne $A B C$ (The Irish companion: Your imigration ABC) in August 2007, an opinion-forming weekly Nasz Gtos (Our Voice) late in 2007, the monthly Wyspa (The Island), or a Polish community bi-weekly emigracja.ie appearing in Cork since February 2006.

The Polish media on the island are an object of interest to Irish organisations - for example, the Media Research Centre at the University of Maynooth. The Centre runs a project on the establishment of media by Poles in Ireland and their use by the Polish community living there. As one of the project's participants has observed, "the inflow of Poles to Ireland is still a very intensive and ongoing process, and the newcomers have a pronounced effect on the Irish community, not only in economic, but also in cultural terms. (...) The media of the given cultural minority are a significant element of the emigration issue - they are not only a source of information about the life, creation and survival of Polish structures and the community. Having their own media gives the Poles living here a high status in comparison with other minorities (...) The Polish 'media market' in Ireland is full of a variety of media that have appeared over a short period of time. This is a situation without a precedent in this country!" (Polski Herald 2007: 2). 
Table 2. Polish newspapers published in Ireland.

\begin{tabular}{|c|c|c|}
\hline Title & Type, circulation, starting date & Main subject of interest \\
\hline Polska Gazeta & weekly; 6,000 copies; May 2005 & $\begin{array}{l}\text { current events in Ireland and Poland, classified } \\
\text { ads, English-language supplement about } \\
\text { interesting sites in Poland }\end{array}$ \\
\hline Polski Express & free bi-weekly & $\begin{array}{l}\text { current news from Poland and Ireland, com- } \\
\text { ments on politics, sport, fashion, cars, etc. }\end{array}$ \\
\hline Polski Herald & $\begin{array}{l}\text { Friday supplement to Dublin's } \\
\text { The Evening Herald November } 2004 \\
\text { (to February 2009) }\end{array}$ & $\begin{array}{l}\text { classified ads, current events in Polish com- } \\
\text { munity, selected pieces of Irish news }\end{array}$ \\
\hline Szpila & monthly, 5,000 copies August 2005 & $\begin{array}{l}\text { issues in Irish culture and effect of Poles } \\
\text { on multiculturalism of Ireland }\end{array}$ \\
\hline
\end{tabular}

Source: own compilation on the basis of www.polishcentre.ie data.

An indicator that Polish emigrants are interested in press readership is the fact that since a Polish supplement to Dublin's Evening Herald has started to appear weekly, each Friday the paper sells about 3,000 copies more than on the other days (information after Polish Socio-Cultural Centre in Dublin, 2007). According to the ARC Rynek i Opinia survey results, $61 \%$ of Poles in Ireland read such titles as Polski Herald or Polski Express (CPWM 2007). These titles are available in practically every 'Polish' shop.

Also numerous are Internet portals devoted to Polish emigrants in Ireland (for example, dublinek.net, or gazeta.ie). Nearly each major town has its own Polish website where one can learn about current events in one's place of stay - for example, www.mycork.org or www.galway.cal.pl. According to the ARC Rynek i Opinia survey, nearly a half of emigrants listen to the radio and as many as $60 \%$ use the Internet, as against a mere $40 \%$ in Poland (CPWM 2007). An increasing number of Internet forums keep appearing that allow an exchange of information on a variety of topics - for example, Polacy w Cork (Poles in Cork - www.cork.xt.pl, Kraina Deszczowców (Rainland www.krainadeszczowcow.net), or Irlandia Po Polsku (Ireland Polish Style - Ireland.banda.pl). A useful function is also performed by the phone and address base of Polish firms in Ireland, at www.polska.ie. Also the
Polish Chaplaincy in Ireland has its Internet address: www.polish-chaplaincy.ie.

Polish radio stations broadcasting over the Net have also appeared and are mostly run by volunteers, usually based in large cities like Dublin or Galway. They include, for example, Radio Anna Livia Dublin, PRL24, polskastacja.pl, and Community Shannon Radio (information after Polish Express - polskiexpress.ie, 2007 and 2009).

\section{Service establishments targeted at the Polish consumer: Cork city}

In 2007 there were six shops located in Cork's downtown service area that were targeted towards the Polish consumer, with a further four in the city's intermediate zone. They are often addressed specifically to the Polish community, as their names show, e.g. Mała Polska (Little Poland), Polska Chata (Polish Cabin), or the supermarket Miś (Teddy Bear, the name referring to the title of a Polish cult film by Stanisław Bareja). The Miś chain has shops in all the major Irish towns and offers, apart from food, such additional services as sending parcels to Poland (Fig. 3A) or ordering the traditional Christmas Eve carp (Fig. 3B). Apart from gro-
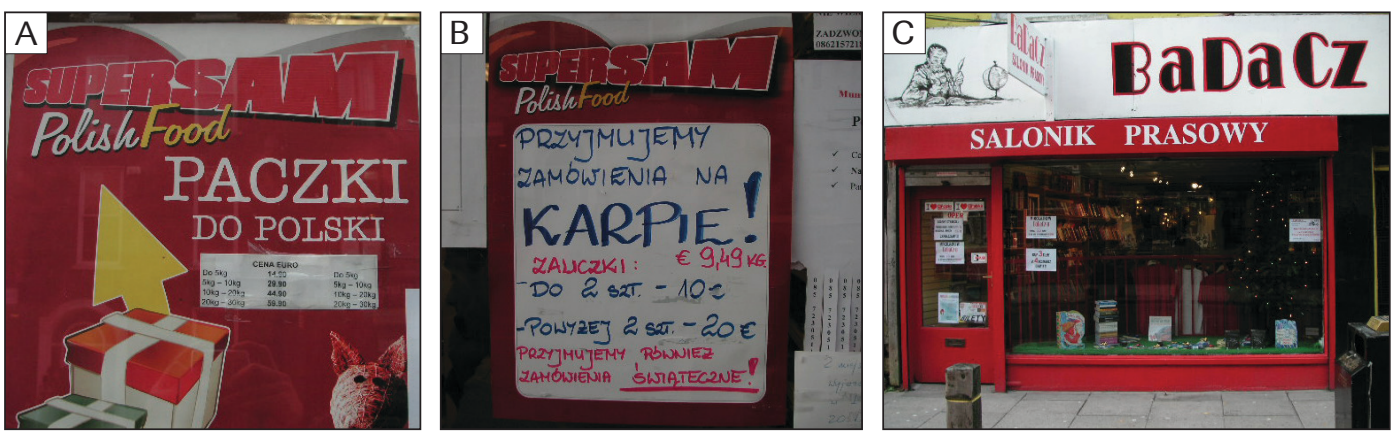

Figure 3. Polish information notices in Cork shops. Explanations of the abbreviations in the text. 
ceries, there is also a press saloon Badacz (Researcher), opened in Cork in May 2007, which sells Polish publications coming out in Ireland and some newspapers, as well as books imported from Poland (Fig. 3C).

Service and shopping facilities addressed to all the migrants from Central and Eastern Europe are also numerous. They are usually owned by Russian-speaking citizens, as proved by such names as Kaunas, or more controversially for some customers, Polski Sklep (the Polish Shop) - back in the USSR. Cork also has a Vejas chain of shops offering Polish and Lithuanian food. The most readily available are foodstuffs with a long shelf life coming from Poland (in jars and powdered); hence the appearance of shop advertisements encouraging their purchase. The shops are mostly supplied from special Dublin food warehouses.

Another interesting development is the fact that Irish shops supply their products with Polish names. One can even speak of some sort of 'Polish information layout', understood as readily visible signage, carrying a variety of different types of information in the city. It is a communication tool indispensable for the operation of the city and its residents and, in accordance with efficiency rules, it should be comprehensible to each city user, and therefore also to the sizeable Polish community using the space of many towns in Ireland.

From the names of bars and restaurants, one can increasingly see that they serve typically Polish dishes, mostly as a result of the Polish cooks who work in them. There has also appeared customer service in Polish in some service establishments (hairdressers, car repair) and in banks. Another development worth noting is a church in Cork that has earned the name of 'Polish' because it offers masses celebrated in this tongue. The parish-affiliated Wspólnota Polonijna (Polish Community) takes care of the décor of masses, the organisation of prayer meetings, or pilgrimages by Poles. In addition, it offers help to those in need, usually seeking lodgings or even a job. After the liturgy there is always a time for those who want to make an announcement or simply get a piece of advice on issues they wrestle with from fellow countrymen who have more experience of living abroad.

There is a social counselling facility in Cork that is intended to serve Polish emigrants, called the Together-Razem Support and Prophylaxis Centre for the Polish Community, which has been in operation since November 2006. It was established as part of the My Cork Polish Association to assist those in the Polish community in County Cork who are facing difficult situations - for example, unemployment, addictions, or family problems. This organisation seeks to support compatriots whose English is too poor for them to use the available service establishments. The Centre collaborates with governmental and non-governmental organisations. It is run by qualified volunteers, and the services it offers are free (information after MyCork Polish Association, 2007 and 2009).

In turn, trained instructors teach in Polish schools set up in four other Irish towns apart from Cork (Dublin, Cavan, Limerick and Waterford). These schools complete children's education in such fields as the history and geography of Poland, the Polish language, mathematics, and the knowledge of society. They are usually affiliated with 'Polish' churches. The classes are free, conducted at weekends in the buildings of Irish schools. As a result of them, Polish children, if they return to the country, will not have to take exams testing their knowledge acquired during the years spent abroad. In Cork there is also a pub called Fred Zeppelins Bar in which regular 'Polish musical soirées' are held each Monday.

\section{Conclusions}

Residents coming from Poland form one of the largest minorities in Ireland. Hence, one can hardly miss manifestations of their presence in their new living environment, whether this is in the form of the establishment of inner links in the group of Polish immigrants in a local setting, or their efforts to make the image of the Polish minority in Ireland a favourable one.

Modern migrations differ radically in their character from those in the past. "Today's notion of 'emigrating' is closer in meaning to that of 'going' or 'leaving'. There is no longer any need to emigrate from the language, culture, to break bonds with the home country and family, or even with the cuisine, because in countries with large emigration inflows there appear shops with Polish products" (Pankowski 2007). In places that have a concentration of Polish residents in Ireland there soon appear shops with Polish products, churches offering the liturgy in Polish (even if only once a month), and schools (usually parish-run). Areas of particular attraction to Poles are County Dublin and County Cork. Polish migrants can also buy the press in their mother tongue, or listen to radio broadcasts conducted by compatriots. In this way there develops a 'Little Poland' social space in Ireland. A schematic model of performance of the Polish migrant community in Ireland in political, cultural, social and economic (service infrastructure) terms is presented in Figure 4.

The years that followed the study period (2004-2007) were a time of marked recession in the economy of Ireland, which was also an effect of the crisis in the world economy (in 2008 the GDP of Ireland was down by 3.0\% from the previous year, and in 2009 it had slumped by as much as $7.0 \%$ ). It was therefore expected that this situation might affect the behaviour pattern of Polish migrants in this country. According to the data published by the Polish Embassy in Dublin, "nearly 70,000 Poles will go back home during the year" (Irish Independent 2008). A study conducted by a leading employment agency in Ireland, CPL, also showed $33 \%$ of Poles covered by it to be thinking about leaving Ireland in 2009, 13\% planned to do so within the next two years, while a mere 9\% responded they "would never leave Ireland" (www. wspolnota-polska.org.pl). Many of those estimates may have already come true, or will do so in the future, but only to some extent, because a substantial proportion of Polish migrants have adapted to the new conditions and decided to wait out the crisis in Ireland. This is corroborated by such facts as the development of shops targeted at the Polish consumer (for example, in Cork, which is one of the areas that has a concentration of Poles), medical centres for Poles, Polish pastoral care centres, and educational institutions for Polish children (with the learning of their mother tongue as part of the syllabus). 


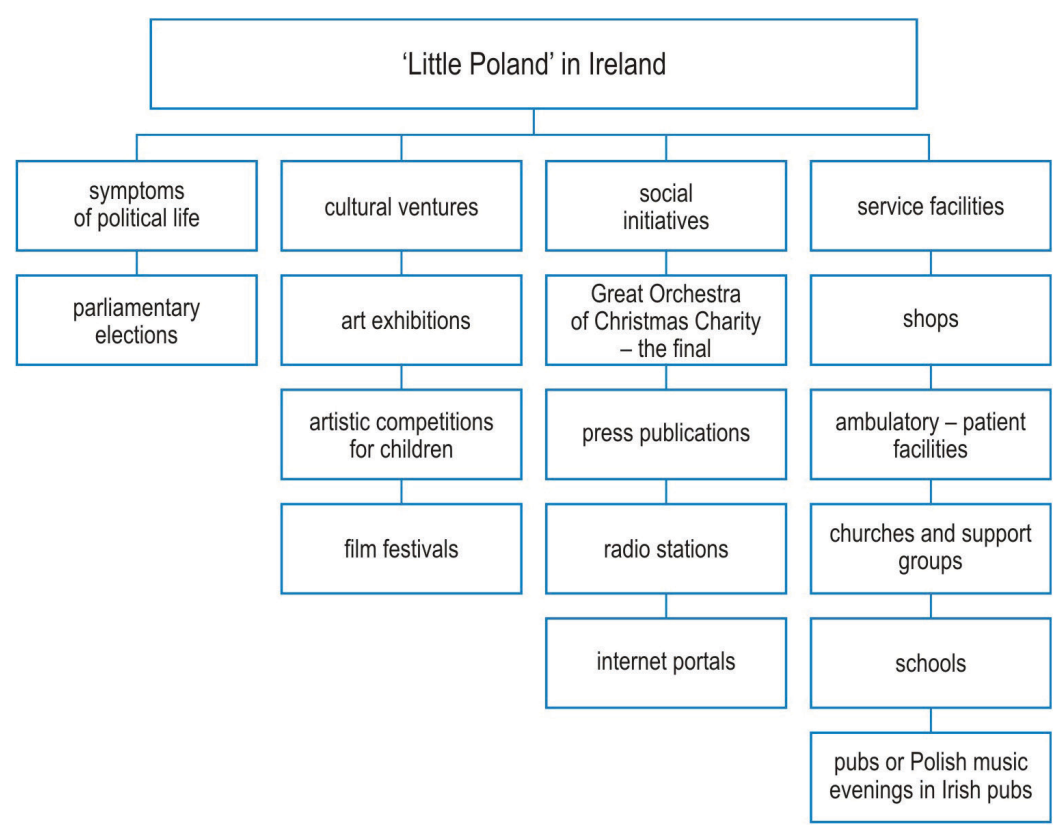

Figure 4. 'Little Poland' in Ireland.

Editors' note:

unless otherwise stated, the sources of tables and figures are the author(s), on the basis of their own research

\section{References}

BAUMAN Z., 1996. Etyka ponowoczesna. Warszawa: Wydawnictwo Naukowe PWN, 350 pp.

CHOJNICKI Z., 1966. Zastosowanie modeli grawitacji i potencjału w badaniach przestrzenno-ekonomicznych. Studia, no. 14, Warszawa: Komitet Przestrzennego Zagospodarowania Kraju Polskiej Akademii Nauk, Państwowe Wydawnictwo Naukowe, 126 pp.

CIACEK P., 2007. Druga fala Wielkiej Emigracji. Raport z badań ilościowych. [in:] L. Kolarska-Bobińska (ed.), Emigrować i wracać. Migracje zarobkowe Polaków a polityka państwa, Warszawa: Instytut Spraw Publicznych, pp. 55-60.

CPWM, 2007. Cooltura Polish Weekly Magazine, no. 26 (101), 30 July 2007.

CSO, 2004. Population and labour force projections. Dublin: Central Statistics Office, $24 \mathrm{pp}$.

CSO, 2006. Census 2006. Volume 4. Usual residence, migration, birthplaces and nationalities, Central Statistics Office of Ireland, Dublin: Government of Ireland, 37 pp.

CZYŻ T., 1996. Zastosowanie modelu potencjału ludności w regionalizacji strukturalnej Polski. [in:] T. Czyż (ed.), Podstawy regionalizacji geograficznej, Poznań: Bogucki Wydawnictwo Naukowe, pp. 45-67.

DŁUGosz Z., 2007. Wybrane aspekty stałej emigracji ludności z Polski za granice po 1989 roku. Czasopismo Geograficzne, vol. 78 , no. $1-2$, pp. 3-22.

DUTKOWSKI M., 2008. Globalizacja, czy jest groźna? [in:] T. Michalski (ed.), Zagrożenia we współczesnym świecie jako temat edukacji geograficzne, Pelplin: Wydawnictwa Szkolne i Pedagogiczne, pp. 37-50.

GŁĄBICKA K., GREWIŃSKI M., 2003. Europejska Polityka Regionalna. Warszawa: Dom Wydawniczy Elipsa, 357 pp.

GRABOWSKA I., LUSIŃSKI C., 2005. Transformacja rynku pracy $w$ kontekście rozwoju gospodarczego Irlandii. Studia Europejskie, no. 4 (36), pp. 101-119.

GRABOWSKA-LUSIŃSKA I., 2008. Migrations from Poland after May 2004 with special focus on the British Isles. Post-accession migration strategies as hidden behind statistics. Espace, Populations, Societes, no. 2008/2, pp. 247-260.

GUS, 2007. Informacja o rozmiarach i kierunkach emigracji z Polski w latach 2004-2006. Wyniki Badań GUS. Notatka informacyjna, Warszawa: Główny Urzad Statystyczny. Departament Badań Demograficznych, 5 pp., http://www. stat.gov.pl/cps/rde/xbcr/gus/LU_infor_o_rozm_i_kierunk_emigra_z_polski_w_latach_2004_2011.pdf [1 April 2012].

GUS, 2008. Informacja o rozmiarach i kierunkach migracji z Polski w latach 2004-2007. Wyniki Badań GUS. Notatka informacyjna, Warszawa: Główny Urząd Statystyczny. Departament Badań Demograficznych, 6 pp., http://www. stat.gov.pl/cps/rde/xbcr/gus/lud_infor_o_rozm_i_kierunk_emigra_z_polski_w_latach_2004_2008.pdf [1 April 2012]. 
IDA IRELAND, 2007. Industrial Development Agency of Ireland homepage. Internet: http://www.idaireland.com [1 April 2012].

IRISH INDEPENDENT, 2008. Irish Independent daily, edition on 9 December 2008.

JAŹWIŃSKA E., 2001. Cechy migracji i migrantów. [in:] E. Jaźwińska, M. Okólski (eds.), Ludzie na huśtawce. Migracje między peryferiami Polski i Zachodu, Warszawa: Wydawnictwo Naukowe Scholar, pp. 110-114.

JuRCZAK E., 2009. Młodzi Polacy w Irlandii - raport z badań. [in:] A. Kobylanek A. (ed.), Wspólnota i różnica. Interdyscyplinarne studia, analizy i rozprawy, Toruń: Wydawnictwo Adam Marszałek, pp. 191-209.

KaczMARCZYk P., 2005. Migracje zarobkowe Polaków w dobie przemian. Warszawa: Wydawnictwo Uniwersytetu Warszawskiego, 360 pp.

KOSER K., 2007. International migration: A very short introduction. Oxford: Oxford University Press, 138 pp.

ŁUCZAK R., 2007. Migracje $i$ ich skutki kulturowe. [in:] M. Czerny (ed.), R. Łuczak, J. Makowski, Globalistyka. Procesy globalne i ich lokalne konsekwencje, Warszawa: Wydawnictwo Naukowe PWN, pp. 82-101.

MATYKOWSKI R., 1990. Struktura przestrzenna Gniezna i przemieszczeń jego mieszkańców. Prace Komisji Geograficzno-Geologicznej PTPN, vol. 22, Warszawa-Poznań: Państwowe Wydawnictwo Naukowe, 136 pp.

MioduszewSKA M., 2008. Selektywność migracji z Polski w świetle danych BAEL/OBM. Biuletyn Migracyjny, no. 16, pp. 3, http://www.migration-news.uw.edu.pl/BiuletynMigracyjny16.pdf [1 April 2012].

NAKONIECZNA J., 2007. Migracje międzynarodowe a rozwój państwa. Żurawia Papers, no. 9, Warszawa: Instytut Stosunków Międzynarodowych Uniwersytetu Warszawskiego, Fundacja Studiów Międzynarodowych, Wydawnictwo Naukowe "Scholar", 126 pp.

NAsz GŁOS, 2007. Nasz Głos weekly magazine. no. 1 (12).

NCG, 2010. The Irish Famine Population Data Atlas 1841-2002. Internet: National Centre for Gecocomputation, http:// ncg.nuim.ie/redir.php?action=projects/famine/explore [1 April 2012].

PANKOWSKI K., 2007. Najnowsza fala emigracji z Polski. Analiza treści dyskusji internetowych. [in:] L. Kolarska-Bobińska (ed.), Emigrować i wracać. Migracje zarobkowe Polaków a polityka państwa, Warszawa: Instytut Spraw Publicznych, pp. 61-81.

Polish Community Association, 2007. Polish Community Association homepage. Internet: http://www.wspolnotapolska.org.pl [30 October 2007].

Polish Community Service in Ireland, 2007. Polish Community Service in Ireland homepage. Internet: http://www. polskidublin.com [15 October 2007].

POLISH EXPRESS, 2009. Polish Express homepage. Internet: http://www.polskiexpress.ie [12 March 2009].

POLISH SCHOOL IN CORK, 2007. Polish School in Cork homepage. Internet: http://www.szkolacork.republika.pl [30 September 2007].

Polish Socio-Cultural Centre in Dublin, 2007. Polish Socio-Cultural Centre in Dublin homepage. Internet: http:// www.polishcentre.ie [30 October 2007].

POLITYKA, 2007. W krainie jurków. Raport o życiu polskiej emigracji w Irlandii - dylematy i oczekiwania. Polityka (weekly magazine), no 11. (2596), 17 March 2007, pp. 4-12.

Polska GAZETA, 2007. Polska Gazeta daily (Ireland). nos. 25, 41.

Polski Herald, 2007. Polski Herald weekly. edition on 12 January 2007.

RaVENSTEIN E.G., 1885. The laws of migration. Journal of the Statistical Society of London, vol. 48, no. 2, pp. 167-235.

ROMANISZYN K., 2003. Kulturowe implikacje międzynarodowych migracji. Biblioteka Polonii. Seria A. Studia, vol. 26, Lublin: Katolicki Uniwersytet Lubelski Jana Pawła II. Instytut Badań nad Polonia i Duszpasterstwem Polonijnym, $165 \mathrm{pp}$.

RZECZPOSPOLITA, 2006. Wyspa spełnionych marzeń. Rzeczpospolita (daily), no. 80 (3804), 4 April 2006, pp. X1.

SadowsKA E., 2008. Centra Integracji Migrantów Zarobkowych w Londynie i Dublinie (EuroMI). [in:] B. Sadowska (ed.), Barka. Ekonomia Społeczna w Praktyce, Poznań: Fundacja Pomocy Wzajemnej BARKA, pp. 233-238.

WIĘCKOWSKI M., 2008. New international mobility of Poles. Espace, Populations, Sociétés, no. 2008/2, pp. 261-270.
(C) Roman Matykowski, Alicja Andrzejewska

(C) Geographia Polonica

(C) Institute of Geography and Spatial Organization,

Polish Academy of Sciences, Warsaw, 2012
Article first received • January 2012 Article accepted • June 2012 
http://rcin.org.pl 